\title{
Flotation Studies on Scheelite Concentrate of Chitral, NWFP, Pakistan
}

\author{
K. R. Kazmi*, M. A. Bhatti, A. Mehmood, M. S. Anwar and S. T. Sheikh \\ Mineral Processing Research Centre, PCSIR Laboratories Complex, Ferozepur Road, Lahore-54600, Pakistan.
}

\begin{abstract}
A scheelite concentrate, containing $32 \% \mathrm{WO}_{3}$, obtained from an indigenous tungsten ore of Chitral, NWFP, Pakistan, has been beneficiated by froth flotation technique to produce high quality tungsten concentrate assaying $64.8 \% \mathrm{WO}_{3}$ with $84.47 \%$ recovery. This paper presents results on the optimization of flotation parameters like $\mathrm{pH}$, pulp density and reagents. The optimum grade and recovery have been obtained at a feed size of $80 \%$ passing $74 \mu \mathrm{m}$, pulp pH of 10.5 , pulp solids $25 \%$, oleic acid $0.30 \mathrm{~kg} / \mathrm{t}$, polyglycol $0.02 \mathrm{~kg} / \mathrm{t}$ and sodium silicate $0.125 \mathrm{~kg} / \mathrm{t}$ of the feed. The obtained tungsten concentrate meets the specifications required to produce tungsten metal and tungsten based chemicals.
\end{abstract}

Key words: Scheelite Concentrate, Beneficiation, Flotation, Grade, Recovery

\section{Introduction}

Tungsten is a whitish-gray metal with many unique properties and a wide variety of uses. Its largest use is as tungsten carbide in cemented carbides. Cemented carbides (also called hard metals) are wear-resistant materials used by the metalworking, mining and contraction industries. Tungsten metal wires, electrodes and contacts are used in lighting, electronic, electrical, heating and welding applications. It is also used to make heavy metal alloys for arnaments, heat sinks and high-density applications, such as weights and counterweights, super alloys for turbine blades, tool steels, and wear-resistant alloy parts and coatings. Tungsten composites are used as a substitute for lead in bullets and shot. Chemical uses of tungsten include catalysts, inorganic pigments and high-temperature lubricants (Shedd, 2001).

The main ores of tungsten are (a) wolframite [(Fe, Mn) $\mathrm{WO}_{4}$ ] having a specific gravity of 7.1-7.9 and it is feebly magnetic and (b) scheelite $\left(\mathrm{CaWO}_{4}\right)$ having a specific gravity of 5.9-6.1. Scheelite is often closely associated with quartz, with which it is easily confused because of the very similar physical appearance of these two minerals. Fortunately, scheelite always fluoresces a characteristic electric blue to yellow color when irradiated with ultraviolet light, which greatly facilitates both prospecting for scheelite and the evaluation of scheelite deposits (Blackburn, 1988).

Tungsten metal has high strategic importance. High prices and ready market for acceptable tungsten concentrates present very attractive incentive for the mining and processing of tungsten ores. Since all tungsten ores are very friable and slime easily, concentration must take place as soon as the mineral has been liberated by either crushing or grinding methods.

\footnotetext{
* Corresponding author: E-mail: sirkazmi@yahoo.com
}

Regardless of the care taken in the selection of the route of beneficiation, a certain portion of the tungsten is going to be slimed, both during the mining and the milling process. In general the ability to recover the slime tungsten means the difference between success or failure of the milling installation and of the preceding mining operations.

The dominating processes for concentration of tungsten ores are gravity concentration and froth flotation methods. The beneficiation process used is dependent upon the type of ore. Experts like Michell and Gisler have excellent review articles on the processing of tungsten ores (Weiss, 1985). In gravity treatment, care should be taken to concentrate the value and the coarsest possible size avoiding over-grinding. Jigs, tables, rag frames, and spirals are commonly used. In original flotation practice, tungsten ores are beneficiated by using a carboxyl collector and sodium silicate as a depressant. Tannin is used as a depressant in case of associated calcite, fluorite, dolomite and apatite. However, it is quite difficult to obtain economic grade as scheelite itself is readily depressed. Many scheelite flotation mills attempted to make a $60 \% \mathrm{WO}_{3}$ concentrate by gravity means or by tabling of the flotation concentrate. Since scheelite is often finely disseminated in the ore body and tends to slime badly on grinding, such operations showed heavy tungsten losses in achieving the desired grade (Adams, 1986, Crozier, 1992, Bernhart, 2002). However, to produce economic tungsten concentrates, tungsten ores are treated by a combination of gravity concentration and flotation of fines (Zhang et al. 2001, Guan et al. 2002) or by an all flotation process. In the latter case, the ore must be ground to sufficient fineness to assure adequate liberation of the scheelite. (Adams, 1986, Crozier, 1992). 
The scheelite ore of Chitral, North Western Frontier Province (NWFP), Pakistan, containing about $0.55 \% \mathrm{WO}_{3}$, was upgraded to $32 \% \mathrm{WO}_{3}$ at Mineral Processing Research Centre (MPRC) of PCSIR Laboratories Complex Lahore, by applying a combination of mineral processing techniques such as gravity concentration and magnetic separation. The studies regarding gravity concentration and magnetic separation have been compiled to report in a separate communication. The tungsten concentrate having $32 \% \mathrm{WO}_{3}$ was further upgraded to $64.8 \% \mathrm{WO}_{3}$ by froth flotation. The present paper describes the results on the optimization of froth flotation parameters like $\mathrm{pH}$, pulp density and reagents for the preparation of high quality tungsten concentrate, containing $64.8 \% \mathrm{WO}_{3}$, from the above concentrate.

\section{Materials and Methods}

For chemical analysis of flotation feed and products, ASTM methods of volumetric and gravimetric analysis were employed (Jeffery, 1989).

To avoid over grinding, the tungsten concentrate of $32 \%$ $\mathrm{WO}_{3}$ obtained from Scheelite ore of Chitral area of Pakistan was ground carefully in a laboratory rod mill so that it may have a fair proportion of free valuable mineral particles for subsequent flotation operation. The mill was $400 \mathrm{~mm}$ long, $160 \mathrm{~mm}$ in diameter and contained rods of different sizes weighing $25 \mathrm{~kg}$, and it worked at a speed of $43 \mathrm{rpm}$. After performing a series of tests, grind size of the feed was found to be $80 \%$ passing $74 \mu \mathrm{m}$ to get the optimum flotation results.

\section{Flotation Tests}

The flotation tests were carried out in a Denver D-12 flotation machine. The study was completed under different set of conditions for the optimization of flotation parameters. The set of conditions were as follows: $\mathrm{pH} 9.5-11.5$, pulp density $20-40 \%$ solids, oleic acid $(0.15-0.40 \mathrm{~kg} / \mathrm{t})$ as collector, sodium silicate $(0.025-0.225 \mathrm{~kg} / \mathrm{t})$ as depressant and Polyglycol $(0.015-0.035 \mathrm{~kg} / \mathrm{t})$ as frother. The conditioning time was $1-5$ minutes and the froth was collected for 5-20 minutes. The cleaning flotation was carried out without addition of any flotation reagents.

\section{Results and Discussions}

Table I indicates presence of $32 \% \mathrm{WO}_{3}, 48.96 \% \mathrm{SiO}_{2}$ and $8.26 \% \mathrm{CaO}$ as major quantities with minor amounts of others in the tungsten concentrate originating from the Scheelite ore of Chitral area of Pakistan. The grade of the tungsten concentrate seems to be very good for beneficiation purpose as the other gangue minerals like quartz and silicates can be reduced effectively by froth flotation technique (Adams, 1986, Crozier, 1992).
Table I: Chemical analysis of tungsten concentrate

\begin{tabular}{l|c}
\hline Constituents & $\%$ \\
\hline $\mathrm{WO}_{3}$ & 32.00 \\
$\mathrm{SiO}_{2}$ & 48.96 \\
$\mathrm{CaO}$ & 08.26 \\
$\mathrm{Fe}_{2} \mathrm{O}_{3}$ & 00.78 \\
$\mathrm{Al}_{2} \mathrm{O}_{3}$ & 05.87 \\
\hline
\end{tabular}

The description of metallurgical balance given in Table II indicates that the tungsten concentrate of Chitral, containing $32 \% \mathrm{WO}_{3}$, can be upgraded up to $55 \%$ at rougher flotation stage with $90.5 \%$ recovery. This recovery has been obtained, as mentioned in Table III, at a feed size of $80 \%$ passing 74 $\mu \mathrm{m}$, pulp pH of 10.5 , pulp solids $25 \%$, oleic acid $0.30 \mathrm{~kg} / \mathrm{t}$,

Table II: Metallurgical balance for tungsten flotation

\begin{tabular}{l|l|l|l}
\hline Product & Wt. \% & $\begin{array}{l}\text { Grade } \\
\mathrm{WO}_{3} \%\end{array}$ & $\begin{array}{l}\text { Recovery } \\
\mathrm{WO}_{3} \%\end{array}$ \\
\hline Cleaner Concentrate & 41.66 & 64.80 & 84.47 \\
Cleaner Tailings & 10.44 & 18.70 & 6.03 \\
(Rougher Concentrate) & $(52.60)$ & $(55.00)$ & $(90.50)$ \\
Rougher Tailings & 47.40 & 6.43 & 9.50 \\
\hline Head Sample & 100.0 & 32.00 & 100.0 \\
\hline
\end{tabular}

polyglycol $0.02 \mathrm{~kg} / \mathrm{t}$ and sodium silicate $0.125 \mathrm{~kg} / \mathrm{t}$ of the feed. It is also important to note from Tables II and III that one cleaning of the rougher concentrate has been ensured a final concentrate grade of $64.8 \% \mathrm{WO}_{3}$ with $84.47 \%$ recovery, without using any additional reagents.

Table III. Optimum parameters of tungsten flotation

\begin{tabular}{l|l|l}
\hline \multirow{1}{*}{ Parameter } & \multicolumn{2}{|c}{ Optimum Value } \\
\cline { 2 - 3 } & \multicolumn{1}{|c}{ Rougher } & \multicolumn{1}{c}{ Cleaner } \\
\hline $\begin{array}{l}\text { Feed size } \\
\text { Pulp pH }\end{array}$ & $\begin{array}{l}\text { 10\% passing } 74 \mu \mathrm{m} \\
\text { Pulp density }\end{array}$ & $\begin{array}{l}80 \% \text { passing } 74 \mu \mathrm{m} \\
10.5\end{array}$ \\
$\begin{array}{l}\text { Collector } \\
\text { (Oleic acid) }\end{array}$ & $0.30 \mathrm{Kg} / \mathrm{T}$ & $20 \%$ solids \\
$\begin{array}{l}\text { Frother } \\
\text { (Polyglycol) }\end{array}$ & $0.02 \mathrm{Kg} / \mathrm{T}$ & Nil \\
$\begin{array}{l}\text { Depressant } \\
\text { (Sodium silicate) }\end{array}$ & $0.125 \mathrm{Kg} / \mathrm{T}$ & Nil \\
$\begin{array}{l}\text { Conditioning time } \\
\text { Flotation time }\end{array}$ & 3 minutes & 1 minutes \\
\hline
\end{tabular}

Table IV indicates the effect of $\mathrm{pH}$ of the pulp on the $\%$ purity and recovery of the product. The maximum purity is achieved at a $\mathrm{pH}$ of 10.5. Scheelite is already known for its propensity to yield better flotation results at alkaline $\mathrm{pH} 10.5$ with oleic acid and our studies too have substantiated the same view (Adams, 1986, Jain, 1986).

It can be seen from Table $\mathrm{V}$ that the pulp density variation has a significant effect on the grade and the recovery of 
Table IV: Effect of pH

\begin{tabular}{c|c|c}
\hline $\mathrm{pH}$ & Grade $\mathrm{WO}_{3} \%$ & Recovery $\mathrm{WO}_{3} \%$ \\
\hline 9.5 & 35 & 40 \\
10 & 46 & 64 \\
10.5 & 55 & 90.5 \\
11 & 48 & 71 \\
11.5 & 34 & 50 \\
\hline
\end{tabular}

Pulp density $25 \%$ solids, Oleic acid $0.3 \mathrm{~kg} / \mathrm{t}$, Polyglycol $0.02 \mathrm{~kg} / \mathrm{t}$, Sodium silicate $0.125 \mathrm{~kg} / \mathrm{t}$, Conditioning time $3 \mathrm{~min}$., Flotation time $10 \mathrm{~min}$

scheelite. It is clear from the result that as the pulp density is reduced from 40 to $20 \%$ solids, the grade of the concentrate improves while the recovery increases up to 91 and then falls as the pulp becomes more and more dilute. At pulp density of $25 \%$ solids, the grade of the rougher concentrate is better than $30 \%$ solids while there is no big difference in the recoveries.

Table V: Effect of \% solids

\begin{tabular}{c|c|c}
\hline$\%$ Solids & Grade $\mathrm{WO}_{3} \%$ & Recovery $\mathrm{WO}_{3} \%$ \\
\hline 20 & 57 & 75 \\
25 & 55 & 90.5 \\
30 & 51 & 91 \\
35 & 45 & 80 \\
40 & 38 & 68 \\
\hline
\end{tabular}

pH 10.5, Oleic acid $0.3 \mathrm{~kg} / \mathrm{t}$, Polyglycol $0.02 \mathrm{~kg} / \mathrm{t}$, Sodium silicate $0.125 \mathrm{~kg} / \mathrm{t}$, Conditioning time $3 \mathrm{~min}$., Flotation time $10 \mathrm{~min}$.

It is obvious from Table VI that an increase in the quantity of collector (oleic acid) up to $0.30 \mathrm{~kg} / \mathrm{t}$ increases the grade and recovery. A dose of $0.30 \mathrm{~kg} / \mathrm{t}$ of oleic acid following by the frother (Polyglycol) dose of $0.02 \mathrm{~kg} / \mathrm{t}$ shows an optimum

Table VI: Effect of collector

\begin{tabular}{c|c|c}
\hline Oleic acid $(\mathrm{Kg} / \mathrm{T})$ & Grade $\mathrm{WO}_{3} \%$ & Recovery $\mathrm{WO}_{3} \%$ \\
\hline 0.15 & 40 & 60 \\
0.20 & 45 & 71 \\
0.25 & 50 & 83 \\
0.30 & 55 & 90.5 \\
0.35 & 53 & 88 \\
0.40 & 48 & 83 \\
\hline
\end{tabular}

pH 10.5, Pulp density $25 \%$ solids, Polyglycol $0.02 \mathrm{~kg} / \mathrm{t}$, Sodium silicate $0.125 \mathrm{~kg} / \mathrm{t}$, Conditioning time $3 \mathrm{~min}$., Flotation time $10 \mathrm{~min}$.

grade and recovery. Further increase in dose of oleic acid shows an adverse effect (Table VI) on grade and recovery due to the development of multi-layers of the collector on the mineral particles that reduce the selectivity. In addition, increase in the dosage of frother (Table VII) also lowers the recovery and does not have significant effect on grade due to over oiling effect (Crozier, 1992, Wills, 1992).
Table VII: Effect of frother

\begin{tabular}{c|c|c}
\hline Polyglycol $(\mathrm{Kg} / \mathrm{T})$ & Grade $\mathrm{WO}_{3} \%$ & Recovery $\mathrm{WO}_{3} \%$ \\
\hline 0.015 & 51 & 86.5 \\
0.020 & 55 & 90.5 \\
0.025 & 55 & 87.5 \\
0.030 & 54.5 & 86 \\
0.035 & 54 & 85 \\
\hline
\end{tabular}

pH 10.5, Pulp density $25 \%$ solids, Oleic acid $0.3 \mathrm{~kg} / \mathrm{t}$, Sodium silicate $0.125 \mathrm{~kg} / \mathrm{t}$, Conditioning time $3 \mathrm{~min}$., Flotation time $10 \mathrm{~min}$.

The separation of gangue from the desired mineral requires effective treatment to remove unwanted from the useful mineral. Sodium silicate fulfills the purpose as it is efficiently depresses the quartz and silicates by making them hydrophilic (Crozier, 1992, Kazmi et al. 2007). It is seen from Table VIII that sodium silicate efficiently depresses the quartz and silicates until an optimum grade and recovery of scheelite is achieved with a dose of $0.125 \mathrm{~kg} / \mathrm{t}$ of the depressant. After that an increase in the dose of sodium silicate shows a negative effect on the grade and recovery probably due to the over coating of the depressant which make scheelite particles hydrophilic.

Table VIII. Effect of depressant

\begin{tabular}{c|c|c}
\hline Sodium silicate $(\mathrm{Kg} / \mathrm{T})$ & Grade $\mathrm{WO}_{3} \%$ & Recovery $\mathrm{WO}_{3} \%$ \\
\hline 0.025 & 49 & 85 \\
0.075 & 53 & 89 \\
0.125 & 55 & 90.5 \\
0.175 & 50 & 86 \\
0.225 & 46 & 80 \\
\hline
\end{tabular}

$\mathrm{pH} 10.5$, Pulp density $25 \%$ solids, Oleic acid $0.3 \mathrm{~kg} / \mathrm{t}$, Polyglycol $0.02 \mathrm{~kg} / \mathrm{t}$, Conditioning time $3 \mathrm{~min}$, Flotation time $10 \mathrm{~min}$.

Conditioning time has very significant effect on the grade of the concentrate but very little on the recovery of scheelite concentrate as it allows the surfaces of the mineral particles to react with the reagents. It appears from Table IX that a prolonged conditioning time peels off conditioner coating on the gangue resulting in lower flotation grade and recoveries. Similarly, grade and recovery decrease with short conditioning

Table IX: Effect of conditioning time

\begin{tabular}{c|c|c}
\hline Conditioning time (Min.) & Grade $\mathrm{WO}_{3} \%$ & Recovery $\mathrm{WO}_{3} \%$ \\
\hline 1 & 45 & 79 \\
2 & 52 & 89 \\
3 & 55 & 90.5 \\
4 & 53 & 90 \\
5 & 52 & 89.5 \\
\hline
\end{tabular}

$\mathrm{pH} 10.5$, Pulp density $25 \%$ solids, Oleic acid $0.3 \mathrm{~kg} / \mathrm{t}$, Polyglycol $0.02 \mathrm{~kg} / \mathrm{t}$, Sodium silicate $0.125 \mathrm{~kg} / \mathrm{t}$, Flotation time $10 \mathrm{~min}$. 
time, because collector remains unable to coat all the mineral particles present in the pulp. A conditioning time of 3 minutes was found to be sufficient for an optimum contact with the mineral particles under the conditions existing in the flotation cell, for an optimum recovery and grade.

Moreover, Table X indicates that the grade of the concentrate falls by almost $2.5 \%$ with 5 minutes increase in the froth collecting period. A flotation time of 10 minutes was found to produce better grade and recovery and this was selected as optimum value.

Table X. Effect of flotation time

\begin{tabular}{c|c|c}
\hline Flotation time (Min.) & Grade $\mathrm{WO}_{3} \%$ & Recovery $\mathrm{WO}_{3} \%$ \\
\hline 5 & 54.5 & 89.4 \\
10 & 55 & 90.5 \\
15 & 52.5 & 90 \\
20 & 50 & 89 \\
\hline
\end{tabular}

pH 10.5, Pulp density $25 \%$ solids, Oleic acid $0.3 \mathrm{~kg} / \mathrm{t}$, Polyglycol $0.02 \mathrm{~kg} / \mathrm{t}$, Sodium silicate $0.125 \mathrm{~kg} / \mathrm{t}$, Conditioning time $3 \mathrm{~min}$.

The chemical analysis of the final tungsten concentrate presented in Table XI shows the presence of $64.80 \% \mathrm{WO}_{3}$, $15.7 \% \mathrm{Ca}$ and $14.13 \% \mathrm{SiO}_{2}$ as major quantities with minor amounts of others.

Table XI. Chemical analysis of final tungsten concentrate

\begin{tabular}{c|c}
\hline Constituents & $\%$ \\
\hline $\mathrm{WO}_{3}$ & 64.80 \\
$\mathrm{SiO}_{2}$ & 14.13 \\
$\mathrm{CaO}$ & 15.70 \\
$\mathrm{Fe}_{2} \mathrm{O}_{3}$ & 00.48 \\
$\mathrm{Al}_{2} \mathrm{O}_{3}$ & 20.35 \\
$\mathrm{P}$ & Nil \\
$\mathrm{S}$ & Nil \\
\hline
\end{tabular}

It is clear that the obtained tungsten concentrate meets the specifications required to produce tungsten metal and tungsten based chemicals as the marketing specification of the high quality tungsten concentrates is $60 \% \mathrm{WO}_{3}$ content with phosphorous and sulfur levels below $0.05 \%$ each (Hawley, 1981, Johnstone, 1961).

\section{Conclusion}

Beneficiation of Scheelite by flotation is considered very sensitive and difficult job. The research and development work established that the indigenous tungsten concentrate, containing $32 \% \mathrm{WO}_{3}$, could be beneficiated to the high grade concentrate assaying $64.80 \% \mathrm{WO}_{3}$ with a recovery of $84.47 \%$. This concentrate seems to be quite suitable for the production of tungsten metal and tungsten based products. It is a big achievement as tungsten concentrate is not available in the international market.
Flotation studies on Scheelite of Chitral area of Pakistan have not been done earlier and the present work is the first investigation of its kind.

\section{Acknowledgements}

The authors are highly grateful to Mr. Sadiq Naeem, Mr. Wasim Anwar and Mr. Tariq Jamshed for their assistance in the course of this work.

\section{References}

Adams R. W. (1986). Mining Chemical Handbook, American Cyanamid Company, NJ, USA, pp112.

Bernhart W. (2002). Processing of scheelite bearing ores, Huettenmaennische Monatshefte, 147: 6.

Blackburn W. H. (1988). Principles of Mineralogy, 1st Ed. W. C. Browns Publishers, Iowa, USA, pp 247-248.

Crozier R. D. (1992). Flotation: Theory, Reagents and Ore Testing, Pergamon Press, New York, USA, pp 253.

Guan Z., Zhang Z., Gao Y. and Liang D. (2002). Study on the mineral processing technique for comprehensive utilization of polymetallic ore bearing tungsten in Jubankeng, Guangdong Youse Jinshu Xuebao, 12: 2.

Hawley G. (1981). The condensed Chemical Dictionary, 10th Ed. VNR Company, New York, USA, pp1064.

Jain S. K. (1986).Ore Processing, 1st Ed. Oxford \& IBH Publishing Co. Pvt. Ltd., New Delhi, India. pp 461.

Jeffery G. H. (1989). Vogel's Text Book of Quantitative Chemical Analysis, 5th Ed. ELBS, Longman Group, Oxford, UK, pp 325-398.

Johnstone S. J. (1961). Minerals for Chemicals and Allied Industries, 2nd Ed. Chapman and Hall, London, UK, pp 652

Kazmi K. R., Anwar M. S., Bhatti M. A. and Shah W. A. (2007). Proposal for development of a graphite plant, Pak. J. Sci. Ind. Res., 50: 3

Shedd K. B. (2001). U. S. Geological Survey, Bureau of Mines Minerals Yearbook, USGS press, Reston, USA, pp 81.1

Weiss N. L. (1985). SME Mineral Processing Hand book, Society of Mining Engineers (SME), New York, USA, Vol.2, Section 27, pp18.

Wills B. A. (1992). Mineral Processing Technology, 5th Ed. Pergamon Press, New York, USA, pp 464.

Zhang Z., Zhang X., Lin R. and Zhou X. (2001). Collecting agent for flotation of tungsten ores and its manufacture and use, Guangdong Youse Jinshu Xuebao, 11: 2.

Received : July 30, 2009;

Accepted : March 25, 2010 